\title{
Spatial variability of snow water equivalent - the case study from the research site in Khibiny Mountains, Russia
}

\author{
Anton Yu. Komarov, Yury G. Seliverstov, Pavel B. Grebennikov, Sergey A. Sokratov* \\ Lomonosov Moscow State University, Faculty of Geography, Laboratory of Snow Avalanches and Debris Flows Lomonosov Moscow \\ State University, Faculty of Geography, Leninskie Gory 1, 119991, Moscow, Russia. \\ ${ }^{*}$ Corresponding author. E-mail: sokratov@geogr.msu.ru
}

\begin{abstract}
The aim of the investigation was assessment of spatial variability of the characteristics of snowpack, including the snow water equivalent (SWE) as the main hydrological characteristic of a seasonal snow cover. The study was performed in Khibiny Mountains (Russia), where snow density and snow cover stratigraphy were documented with the help of the SnowMicropen measurements, allowing to determine the exact position of the snow layers' boundaries with accuracy of $0.1 \mathrm{~cm}$. The study site was located at the geomorphologically and topographically uniform area with uniform vegetation cover. The measurement was conducted at maximum seasonal SWE on 27 March 2016. Twenty vertical profiles were measured along the $10 \mathrm{~m}$ long transect. Vertical resolution depended on the thickness of individual layers and was not less than $10 \mathrm{~cm}$. The spatial variation of the measured snowpack characteristics was substantial even within such a homogeneous landscape. Bulk snow density variability was similar to the variability in snow height. The total variation of the snowpack SWE values along the transect was about $20 \%$, which is more than the variability in snow height or snow density, and should be taken into account in analysis of the results of normally performed in operational hydrology snow course SWE estimations by snow tubes.
\end{abstract}

Keywords: Snow water equivalent; Snow height; Snow density; Accuracy of measurements.

\section{INTRODUCTION}

The temporal and spatial variability of the measurable snow cover characteristics (snow cover height, density and stability) shows the possibility of $100 \%$ difference between a point-based estimate and a mean for a corresponding horizontal profile of tens meters length, with different variability in different climate conditions (Chernous et al., 2015). Analysis of variability of distinct layers constructing the snow cover based on their penetration resistance (being a representation of snow microstructure including snow density) shows different degrees of autocorrelation for the penetration resistance from $4 \mathrm{~m}$ to more than $20 \mathrm{~m}$ on a slope from layer to layer (Kronholm et al., 2004). Understanding such variability is of high importance for snow avalanche formation research (Brown and Armstrong, 2008; Fierz et al., 2009). However, in operational hydrology the major parameter of concern is the mean snow water equivalent (SWE) in a catchment, with the spatial SWE variability regulated by topography, wind regime and vegetation (Grünewald et al., 2013; Revuelto et al., 2014).

The usual approach is the estimation of a SWE by repeated measurements along a snow course at the distances of dozens or hundreds meters (Elder et al., 1998; Rasmus, 2013) or more detailed estimation of SWE in the areas with selected uniform landscape features (Fassnacht et al., 2010). It is usually accepted that the spatial variability in snow cover density is significantly smaller than the spatial variability in the snow cover height (Mizukami and Perica, 2008; Sturm et al., 2010). Thus, the snow cover height can be considered as the representation of the SWE at an area of hydrological investigations (i.e. Singh, 2016). This simplifies the task of the SWE estimation and allows incorporation of the results of the remote measurements of snow cover height to hydrological investigations (Deems et al., 2008; Trujillo et al., 2007), also required for validation of the distributed or lumped snow models based on measured snow cover characteristics (Holko et al., 2009).
Published results on estimation of the accuracy of snow density measurements by different techniques show up to $9 \%$ difference in reported value in dependence on the type of snow (Conger and McClung, 2009; Proksch et al., 2016). The snow density variability obtained by the same observer using the same method of measurement is considered as a correct quantification of the true variability.

Evidently, the combination of the snow cover height and the snow cover density, as presented in SWE, can be more variable from point to point than each of these parameters alone. Both should theoretically differ more between different landscapes than among several measurements in one topographically uniform area with uniform vegetation. However, the variability can be expected in the nature even in the latter case, and a quantified example of such variability is presented below.

\section{THE SITE AND METHODOLOGY}

The study site was located at the Lomonosov Moscow State University meteorological station in Kirovsk (Murmansk Re-

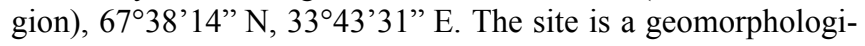
cally and topographically uniform area covered with natural grass. The climate conditions of the investigated region are characterized by long duration of winter period with high repeatability of blizzards, strong winds and low temperatures. Melting events are extremely rare during the winter seasons, although the ice layers may form on the snow surface in spring. The data analyzed in this work were measured on 27 March 16 (time of maximum seasonal SWE). Twenty consecutive measurements along the $10 \mathrm{~m}$ long transect with horizontal resolution of $50 \mathrm{~cm}$ at a geomorphologically and topographically uniform area were made. First, the SnowMicropen (SMP) (Schneebeli and Johnson, 1998) measurements were made along the transect. Then, the $10 \mathrm{~m}$ long snowpit along the transect was dug. Snow structure was described and snow layers were determined in accordance with Fierz et 
al. (2009) taking into account also the SMP data. As a result, nine distinct snow layers were detected. The distance between the 20 resulting vertical snow profiles was set by the tape measure. The snow density in each vertical was measured by the standard "Swiss" "box cutter". Vertical resolution of the measurements varied depending on the thickness of the layers (Proksch et al., 2016). For the layers thinner than $10 \mathrm{~cm}$ three density measurements were made at the same snow height in the middle of the layer and the mean value was calculated. For thicker layers, the set of "the same height" three measurements were made with no more than $10 \mathrm{~cm}$ vertical distance between the selected levels. The total number of measurements for each of the twenty snow density profiles was about 40 .

Data analysis was carried out on the base of detailed description of snow microstructure visually determined in the snowpit and checked by the SMP profiles snow layers. Horizontal and vertical distributions of measured snow characteristics were constructed and the spatial variability was statistically processed. Detailed presentation of all data is out of the scope of this work. We focus on the SWE variability along the transect. SWE for each vertical profile was calculated from the density and thickness of the individual layers.

\section{RESULTS}

Snow height (20 points) along the transect varied from 101 to $114 \mathrm{~cm}$, with the average value of $109 \mathrm{~cm}$ (Fig. 1a). Thus, the variation of this parameter along the transect was $12 \%$. The variation of the thickness of individual snow layers along the transect was much higher which is documented in Fig $1 \mathrm{~b}$.
The snow density in individual snow layers (as represented by three measurements per layer in each vertical profile) varied from 118 to $341 \mathrm{~kg} / \mathrm{m}^{3}$ (Fig. 1b). The densities of ice layers were not measured in the field and were substituted by the theoretical value of $900 \mathrm{~kg} / \mathrm{m}^{3}$ for calculation of SWE of individual profiles. The bulk snow density was calculated as the ratio of the mean SWE and total snow height for each of the 20 profiles. It varied from 265 to $299 \mathrm{~kg} / \mathrm{m}^{3}$ (Fig. 1a), which represents the variation of $12 \%$. The average value of the bulk density was $284 \mathrm{~kg} / \mathrm{m}^{3}$.

The SWE of the snowpack calculated for each vertical profile varied from 280 to $340 \mathrm{~mm}$, with the mean value of $312 \mathrm{~mm}$ for the transect in total (Fig. 1c). This gave the variation of $20 \%$ at the time of seasonal SWE maximum at the studied site.

\section{CONCLUSION}

According to our results the variation of SWE at the date of maximal seasonal SWE in 20 profiles $50 \mathrm{~cm}$ apart along a $10 \mathrm{~m}$ transect at a geomorphologically and topographically uniform area with uniform vegetation cover can be $20 \%$ for the snow cover of about $1 \mathrm{~m}$ height. The variability in snow height and mean snow cover density, averaged per each profile, did not exceed $12 \%$. This disagrees with common assumption that the spatial variability in snow cover density is significantly less than the spatial variability in the snow cover height. Our results showed that they can be the same which means that the spatial variability in snow cover height does not necessary represent the spatial variability in SWE. Spatial variability of snow height
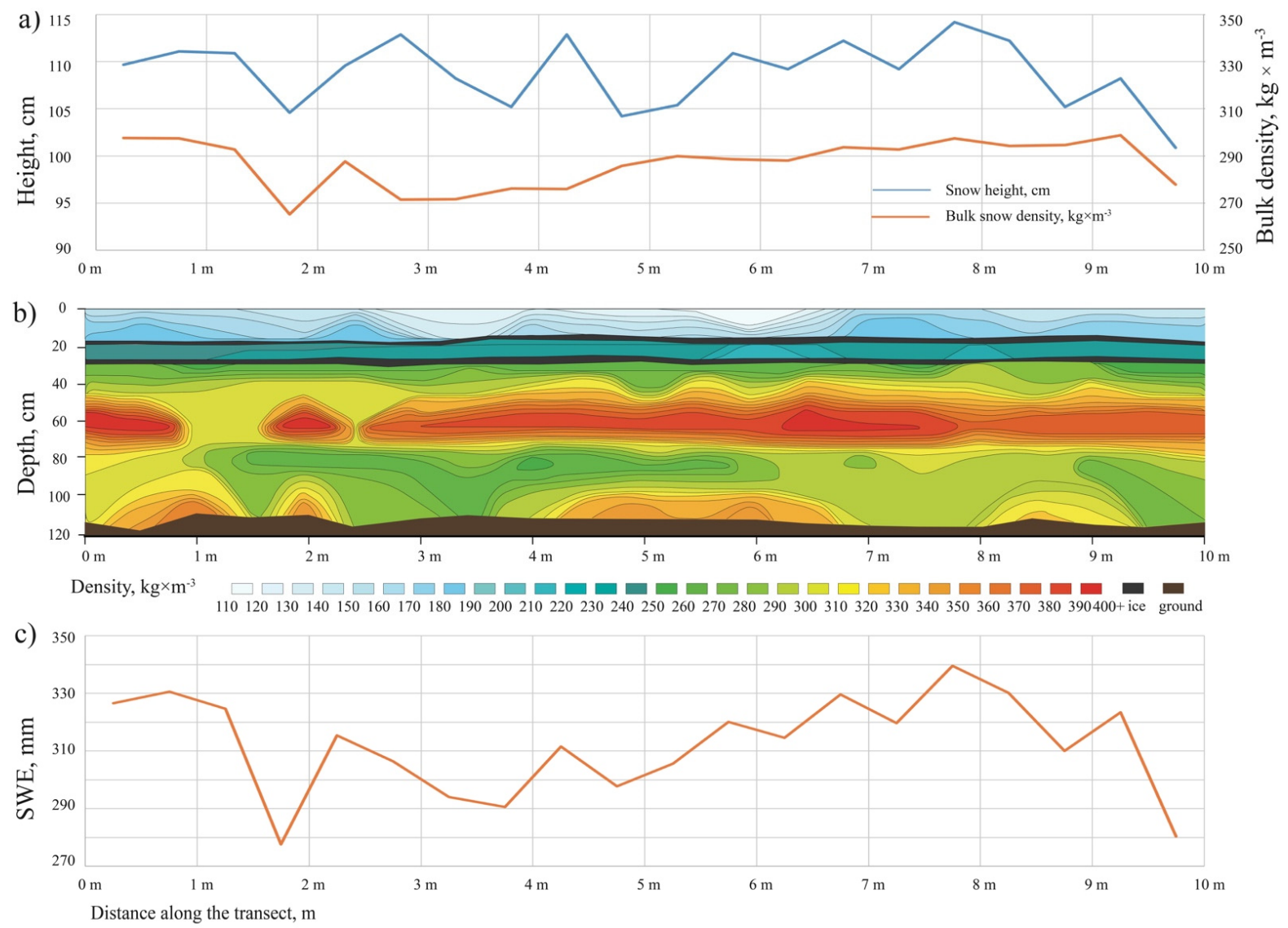

Fig. 1. a) Snow height and bulk snow density along the 10-m transect. b) Snow density variability along the 10-m transect. c) Snow water equivalent (SWE) along the 10-m transect. 
may represent the spatial variability of SWE when comparing different landscapes or is focused on continental scale SWE and snow density variability (Bormann et al., 2013; Zhong et al., 2014) or the effect of terrain characteristics on the SWE (López-Moreno et al., 2013). However, it should be kept in mind that one single SWE measurement by snow tube per uniform area with the spatial resolution of $500 \mathrm{~m}$ (Hannula et al., 2016) can be significantly biased. SWE difference close to $20 \%$ was observed between the two verticals $1 \mathrm{~m}$ apart (Fig. 1c). Measurements made every 5-10 m which are considered as "accurate" enough (Fassnacht et al., 2010) each can have an accuracy of about $\pm 10 \%$, and their averaging would not necessarily represent the actual mean value for the surrounding area. Snow height measurement alone cannot substitute the SWE assessment. Based on the presented SWE analysis and the snow microstructure data which are beyond the scope of this article we assume that the greatest spatial variability of the SWE values along the profile should be observed during winters characterized by long cold periods, rapid temperature changes (leading to the increase of temperature gradient and the vapor migration within the snowpack), as well as heavy blizzards with high wind velocities (leading to dense layers' formation).

Acknowledgement. The study was funded by the RSF project No 16-17-00104.

\section{REFERENCES}

Bormann, K.J., Westra, S., Evans, J.P., McCabe, M.F., 2013. Spatial and temporal variability in seasonal snow density. Journal of Hydrology, 484, 63-73. DOI: 10.1016/j.jhydrol.2013.01.032.

Brown, R., Armstrong, R.L., 2008. Snow cover data: Measurement, products and sources. In: Armstrong, R., Brun, E. (Eds.): Snow and Climate - Physical Processes, Surface Energy Exchange and Modelling. Cambridge University Press, Cambridge, UK, pp. 181-216.

Chernous, P.A., Seliverstov, Y.G., Suchkov, V.E., 2015. Snow variability effect upon avalanching. Led i Sneg [Ice and Snow], 55, 2, 53-59. DOI: 10.15356/2076-6734-2015-2-5359. (In Russian, with English summary.)

Conger, S.M., McClung, D.M., 2009. Comparison of density cutters for snow profile observations. Journal of Glaciology, 55, 189, 163-169. DOI: 10.3189/002214309788609038.

Deems, J.S., Fassnacht, S.R., Elder, K.J., 2008. Interannual consistency in fractal snow height patterns at two Colorado mountain sites. Journal of Hydrometeorology, 9, 5, 977-988. DOI: 10.1175/2008JHM901.1.

Elder, K., Rosenthal, W., Davis, R.E., 1998. Estimating the spatial distribution of snow water equivalence in a montane watershed. Hydrological Processes, 12, 10-11, 1793-1808. DOI: 10.1002/(SICI)1099-1085(199808/09)12:10/11<1793::AIDHYP695>3.0.CO;2-K.

Fassnacht, S.R., Heun, C.M., López-Moreno, J.I., Latron, J., 2010. Variability of snow density measurements in the Rio Esera Valley, Pyrenees Mountains, Spain. Cuadernos de Investigación Geográfica, 36, 1, 55-72. DOI: 10.18172/cig. 1227.

Fierz, C., Armstrong, R.L., $\quad$ Durand, Y., $\quad$ Etchevers, P., Greene, E., McClung, D.M., Nishimura, K., Satyawali, P.K., Sokratov S.A., 2009. The international classification for seasonal snow on the ground. (UNESCO, IHP-VII, IACS contribution No 1). Technical Documents in Hydrology No 83. UNESCO/Division of Water Sciences, Paris, 80 p.
Grünewald, T., Stötter, J., Pomeroy, J.W., Dadic, R., Moreno, Baños, I., Marturià, J., Spross, M., Hopkinson, C., Burlando, P., Lehning, M., 2013. Statistical modelling of the snow height distribution in open Alpine terrain. Hydrology and Earth System Sciences, 17, 8, 3005-3021. DOI: 10.5194/hess-17-3005-2013.

Hannula, H.-R., Lemmetyinen, J., Kontu, A., Derksen, Ch., Pulliainen, J., 2016. Spatial and temporal variation of bulk snow properties in northern boreal and tundra environments based on extensive field measurements. Geoscientific Instrumentation, Methods and Data Systems, 5, 2, 347-363. DOI: $10.5194 /$ gi-5-347-2016.

Holko, L., Sokratov, S.A., Shmakin, A.B., Kostka, Z., 2009. Simulation of snow water equivalent by mathematical models of different complexity. Materialy glyatsiologicheskikh issledovanii [Data on glaciological studies], 107, 72-80.

Kronholm, K., Schneebeli, M., Schweizer, J., 2004. Spatial variability of micropenetration resistance in snow layers on a small slope. Annals of Glaciology, 38, 202-208. DOI: 10.3189/172756404781815257.

López-Moreno, J.I., Fassnacht, S.R., Heath, J.T., Musselman, K.N., Revuelto, J., Latron, J., Morán-Tejeda, E., Jonas, T., 2013. Small scale spatial variability of snow density and height over complex alpine terrain: Implications for estimating snow water equivalent. Advances in Water Resources, 55, 40-52. DOI: 10.1016/j.advwatres.2012.08.010.

Mizukami, N., Perica, S., 2008. Spatiotemporal characteristics of snowpack density in the mountainous regions of the Western United States. Journal of Hydrometeorology, 9, 6, 1416-1426. DOI: 10.1175/2008JHM981.1.

Proksch, M., Rutter, N., Fierz, Ch., Schneebeli, M., 2016. Intercomparison of snow density measurements: bias, precision, and vertical resolution. The Cryosphere, 10, 1, 371-384. DOI: $10.5194 /$ tc-10-371-2016.

Rasmus, S., 2013. Spatial and temporal variability of snow bulk density and seasonal snow densification behavior in Finland. Geophysica, 49, 1-2, 53-74.

Revuelto, J., López-Moreno, J.I., Azorin-Molina, C., VicenteSerrano, S.M., 2014. Topographic control of snowpack distribution in a small catchment in the central Spanish Pyrenees: intra- and inter-annual persistence. The Cryosphere, 8 , 5, 1989-2006. DOI: 10.5194/tc-8-1989-2014.

Schneebeli, M., Johnson, J.B., 1998. A constant-speed penetrometer for high-resolution snow stratigraphy. Annals of Glaciology, 26, 107-111. DOI: 10.3189/1998AoG26-1-107111.

Singh, V.P., 2016. Handbook of Applied Hydrology. 2nd Ed. (Mechanical Engineering). McGraw-Hill Education, 1440 p.

Sturm, M., Taras, B., Liston, G.E., Derksen, C., Jonas, T., Lea, T., 2010. Estimating snow water equivalent using snow height data and climate classes. Journal of Hydrometeorology, 11, 6, 1380-1394. DOI: 10.1175/2010JHM1202.1.

Trujillo, E., Ramírez, J.A., Elder, K.J., 2007. Topographic, meteorologic, and canopy controls on the scaling characteristics of the spatial distribution of snow height fields. Water Resources Research, 43, 7, W07409. DOI: 10.1029/2006WR005317.

Zhong, X., Zhang, T., Wang, K., 2014. Snow density climatology across the former USSR. The Cryosphere, 8, 2, 785799. DOI: $10.5194 /$ tc-8-785-2014.

Received 22 August 2017 Accepted 21 March 2018 